Editorial

\title{
Environmental Applications of Photocatalytic Processes
}

\author{
Luigi Rizzo ${ }^{1, * \mathbb{C}}$ and Adrián M.T. Silva ${ }^{2, * \mathbb{C}}$ \\ 1 Department of Civil Engineering, University of Salerno, Via Giovanni Paolo II, 132-84084 Fisciano, SA, Italy \\ 2 Laboratory of Separation and Reaction Engineering - Laboratory of Catalysis and Materials (LSRE-LCM), \\ Faculdade de Engenharia da Universidade do Porto, Rua Dr. Roberto Frias, 4200-465 Porto, Portugal \\ * Correspondence: 1.rizzo@unisa.it (L.Z.); adrian@fe.up.pt (A.M.T.S.)
}

Received: 31 July 2020; Accepted: 24 September 2020; Published: 31 October 2020

Photocatalytic processes have been investigated in different environmental fields, but their applications at full scale are still scarce. The main scope of this special issue (SI) was to collect scientific works (research and review papers) that can testify the efforts of scientists worldwide to improve the efficiency of photocatalytic processes and contribute to fill the gap between these processes and consolidated ones, in order to speed up their application at full scale. Accordingly, this SI includes publications on (i) new methods to evaluate photocatalytic activity, (ii) new photocatalysts (also visible light active) purposely synthesized for (waste) water treatment and disinfection and (iii) photocatalytic $\mathrm{CO}_{2}$ reduction (review paper). The contents of the papers published in this SI are summarized in the following paragraphs.

The measurement of the photocatalytic activity is quite time-consuming and new methods were investigated in the first two publications. Janus and coworkers proposed a new method for a quick comparison of the photocatalytic activity of building substrates by studying different types of modified gypsum materials [1]. Tapia-Tlatelpa et al. focused their work on online monitoring for the decolorization of six azo dyes in wastewater, analyzing the spectrum measured in situ through the light scattering provided by the photocatalyst in slurry systems [2].

The six following publications are focused on the synthesis of new photocatalytic materials.

A solvothermal method was used to prepare $\mathrm{KSb}_{5} \mathrm{~S}_{8}$ with a layered crystal structure and its photocatalytic activity was evaluated in the degradation of methyl orange [3]. The degradation efficiency under visible light irradiation was considerably higher than those obtained with $\mathrm{TiO}_{2}-\mathrm{P} 25$ and $\mathrm{g}-\mathrm{C}_{3} \mathrm{~N}_{4}$ materials, and the promising results will be useful to design improved sulfide photocatalytic materials with layered crystal structures. Zammit et al. investigated a new cerium-doped zinc oxide $(\mathrm{Ce}-\mathrm{ZnO})$ photocatalyst that was also compared to $\mathrm{TiO}_{2}-\mathrm{P} 25$ (both immobilised on a metallic support) as a possible option in urban wastewater tertiary treatment [4]. Ce-ZnO is an easy and cheap photocatalyst to produce and immobilise, showing higher activity than the benchmark $\mathrm{TiO}_{2}-\mathrm{P} 25$ photocatalyst against the tested antibiotics and bacteria, including antibiotic-resistant bacteria. New photocatalysts have been herein investigated also for water treatment and particularly for the removal of organic precursors (humic acids) of chlorination by-products [5], the photocatalytic performance of $\mathrm{LaFeO}_{3}$ under simulated solar light irradiation being compared to the metal $(\mathrm{Cu})$ modified version of this photocatalyst. A green and facile method was used to prepare reduced graphene oxide (rGO) and subsequently tested under visible light [6]. The results showed that $\mathrm{rGO}$ in combination with $\mathrm{TiO}_{2}$ led to a significant improvement for both adsorption of Alizarin Red S on the catalyst surface and photodegradation efficiencies when compared to those obtained without rGO. Photocatalysts based on bismuth nanoparticles and zinc oxide $(\mathrm{BiNPs} / \mathrm{ZnO})$ with different $\mathrm{Bi}$ loadings were successfully prepared via a facile chemical method [7]. The performance of the photocatalytic $\mathrm{Cr}(\mathrm{VI})$ removal under visible light irradiation indicated that BiNPs/ZnO exhibited a superior removal performance to bare 
$\mathrm{ZnO}, \mathrm{Bi}$, and the counterpart sample prepared using a physical mixing method. In another work, $\mathrm{Ag}_{3} \mathrm{PO}_{4} / \mathrm{g}-\mathrm{C}_{3} \mathrm{~N}_{4}$ composites were synthesized by hydrothermal method to investigate its photocatalytic disinfection potential using bacteriophage $\mathrm{f} 2$ as the model virus [8]. A complete inactivation of $\mathrm{f} 2$ with concentration of $3 \times 10^{6} \mathrm{PFU} / \mathrm{mL}$ was reached within $80 \mathrm{~min}$ in the presence of this composite material.

Photocatalytic $\mathrm{CO}_{2}$ reduction is emerging as an affordable route for abating its ever increasing concentration. However, many constraints are still required to be addressed in view of commercial-scale applications. In particular, a review paper remarks [9], through the discussion of their relevance and impact, how some parameters (such as light source, reaction parameters, and type of photoreactors used) are not normally given appropriate attention.

We trust that such papers will be of interest of journal readers.

\section{References}

1. Janus, M.; Zając, K.; Ehm, C.; Fast, D.S. Method for Testing the Photocatalytic Performance of Modified Gypsum. Catalysts 2019, 9, 693. [CrossRef]

2. Tapia-Tlatelpa, T.; Trull, J.; Romeral, L. In situ Decolorization Monitoring of Textile Dyes for an Optimized UV-LED/TiO ${ }_{2}$ Reactor. Catalysts 2019, 9, 669. [CrossRef]

3. Li, Y.; Wu, M.; Wang, Q.; Wang, K.; Zhang, H.; Quan, X.; Zhang, B.; Yang, D. High-Efficiency Visible Light Responsive Sulfide $\mathrm{KSb}_{5} \mathrm{~S}_{8}$ Photocatalyst with a Layered Crystal Structure. Catalysts 2019, 9, 529. [CrossRef]

4. Zammit, I.; Vaiano, V.; Ribeiro, A.R.; Silva, A.M.T.; Manaia, C.M.; Rizzo, L. Immobilised Cerium-Doped Zinc Oxide as a Photocatalyst for the Degradation of Antibiotics and the Inactivation of Antibiotic-Resistant Bacteria. Catalysts 2019, 9, 222. [CrossRef]

5. Turkten, N.; Sora, I.N.; Tomruk, A.; Bekbolet, M. Photocatalytic Degradation of Humic Acids Using $\mathrm{LaFeO}_{3}$. Catalysts 2018, 8, 630. [CrossRef]

6. Rommozzi, E.; Zannotti, M.; Giovannetti, R.; D’Amato, C.A.; Ferraro, S.; Minicucci, M.; Gunnella, R.; di Cicco, A. Reduced Graphene Oxide/ $\mathrm{TiO}_{2}$ Nanocomposite: From Synthesis to Characterization for Efficient Visible Light Photocatalytic Applications. Catalysts 2018, 8, 598. [CrossRef]

7. Yuan, X.; Feng, Z.; Zhao, J.; Niu, J.; Liu, J.; Peng, D.; Cheng, X. Significantly Enhanced Aqueous Cr(VI) Removal Performance of $\mathrm{Bi} / \mathrm{ZnO}$ Nanocomposites via Synergistic Effect of Adsorption and SPR-Promoted Visible Light Photoreduction. Catalysts 2018, 8, 426. [CrossRef]

8. Cheng, R.; Shen, Li.; Yu, Ji.; Xiang, Sh.; Zheng, X. Photocatalytic Inactivation of Bacteriophage f2 with $\mathrm{Ag}_{3} \mathrm{PO}_{4} / \mathrm{g}-\mathrm{C}_{3} \mathrm{~N}_{4}$ Composite under Visible Light Irradiation: Performance and Mechanism. Catalysts 2018, 8, 406. [CrossRef]

9. Ali, S.; Flores, M.C.; Razzaq, A.; Sorcar, S.; Hiragond, C.B.; Kim, H.R.; Park, Y.H.; Hwang, Y.; Kim, H.S.; Kim, H.; et al. In Gas Phase Photocatalytic $\mathrm{CO}_{2}$ Reduction, A Brief Overview for Benchmarking. Catalysts 2019, 9, 727. [CrossRef]

Publisher's Note: MDPI stays neutral with regard to jurisdictional claims in published maps and institutional affiliations. 